\title{
Profil Histologi Duodenum Berbagai Itik Lokal Di Kabupaten Semarang
}

\author{
Nur Indah Apriliyani, Muhammad Anwar Djaelani dan Silvana Tana \\ Laboratorium Biologi Struktur dan Fungsi Hewan, Jurusan Biologi, Fakultas Sains dan Matematika, \\ Universitas Diponegoro Jalan Prof. H. Sudarto, Tembalang, Semarang \\ e-mail : apriliyaniindah995@gmail.com.,muhammadanwardjaelani@ rocketmail.com.,silvanatana@yahoo.co.id
}

\begin{abstract}
Local duck had been widely cultivated not only as a producer of eggs processed as salted egg but also there are cultivated as broiler ducks. The efforts to improve the productivity of ducks can be seen from the effectiveness of the process of absorption of nutrients in the duodenum, so the use of energy in the metabolic process can be optimized for adding mass and volume of the cell. This study aims to determine the duodenum profile of the histological structure covered the lumen diameter, villous height and number of goblet cells of Magelang ducks, Tegal ducks and Pengging ducks. This study used a completely randomized design (CRD) with three treatments (Magelang ducks, Tegal ducks and Pengging ducks) and 6 replications. The measured variable was the long intestine tenue, lumen diameter, villous height and number of goblet cells. Data were analyzed using analysis of variance (ANOVA) with a differentiation factor was the type of duck. The realdifferences data were analyzed using advanced test of Duncan at the level of 95\%. The results showed long intestine tenue, lumen diameter and height of the villi were not significantly different at each Magelang ducks, Tegal ducks, Pengging ducks. The number of goblet cells in Magelang ducks and Tegal ducks showed significantly different, but not on Pengging Ducks. The conclusion of the study was the length of the intestine tenue, lumen diameter and height of villous had no real effect on three types of ducks.
\end{abstract}

Keywords: Local ducks, duodenum, histological

\begin{abstract}
Abstrak
Itik lokal telah banyak dibudidayakan tidak hanya sebagai penghasil telur yang diolah sebagai telur asin tapi juga ada yang dibudidayakan sebagai itik pedaging. Usaha untuk meningkatkan produktifitas itik dapat dilihat dari efektivitas proses absorbsi nutrisi didalam duodenum, sehingga penggunaan energi dalam proses metabolisme dapat optimum dalam menambah massa dan volume sel. Penelitian ini bertujuan untuk mengetahui profil struktur histologi duodenum yang meliputi diameter lumen, tinggi vili dan jumlah sel goblet pada Itik Magelang, Itik Tegal, dan Itik Pengging. Penelitian ini menggunakan metode Rancangan Acak Lengap (RAL) dengan 3 perlakuan (itik Magelang, itik Tegal dan itik Pengging) dan 6 kali ulangan. Variabel yang diukur yaitu panjang intestinum tenue, diameter lumen, tinggi vili dan jumlah sel goblet. Data dianalisis menggunakan analisis of varians (ANOVA) dengan faktor pembeda adalah jenis itik. Data yang berbeda nyata dianalisis dengan menggunakan uji lanjut Duncan pada taraf kepercayaan $95 \%$. Hasil penelitian menunjukan panjang intestinum tenue, diameter lumen dan tinggi vili tidak berbeda nyata pada masing-masing itik Magelang, itik Tegal, itik Pengging. Jumlah sel goblet pada itik Magelang dan itik Tegal menunjukan berbeda nyata, tetapi tidak pada Itik Pengging. Kesimpulan penelitian adalah panjang intestinum tenue, diameter lumen dan tinggi vili tidak berpengaruh nyata pada ketiga jenis Itik.
\end{abstract}

Kata Kunci : Itik lokal, duodenum, gambaran histologi

\section{PENDAHULUAN}

Itik lokal telah banyak dibudidayakan tidak hanya sebagai penghasil telur yang tetapi juga ada yang dibudidayakan sebagai itik pedaging. Itik merupakan salah satu komoditi utama penghasil telur yang memberi kontribusi pada pemenuhan kebutuhan protein hewani. Konsumsi protein hewani masyarakat di Indonesia pada tahun 20022005 memiliki kisaran rata-rata 5,27\% per tahun. Kebutuhan protein hewani dari itik petelur telah menyumbang sebanyak $20 \%$ dari total kebutuhan proten hewani nasional (Setiawan, 2006). 
Saluran pencernaan unggas terdiri dari cavum oris, esophagus, ingluvies (tembolok), proventriculus, ventriculus, intestinum, dan kloaka. Saluran pencernaan berfungsi untuk mengubah nutrisi yang terdapat ada makanan menjadi monosakarida, asam amino dan asam lemak, sehingga dapat diabsorbsi oleh intestinum sebagai sumber energi, membangun senyawasenyawa lain untuk kepentingan metabolisme (Murti, 2003). Kapasitas daya dukung proses pencernaan terhadap pakan yang diberikan dan penyerapan nutrisi dapat dipengaruhi oleh luas permukaan epithel usus, jumlah lipatan yang ada didalamnya, tinggi vili, banyaknya vili dan mikrovili yang memperluas bidang penyerapan (Ruttanavut et al., 2009). Proses penyerapan nutrisi juga dapat dipengaruhi oleh tinggi dan luas permukaan vili, duodenum, jejunum, dan ileum (Sugito dkk., 2007).

Panjang dan lebarnya luas penampang usus halus dapat berpengaruh terhadap kemampuan pencernaan dan penyerapan nutrisi. Pertambahan berat dan panjang usus halus, disertai juga oleh pertambahan besar rongga di dalam usus halus, serta pertambahan luas permukaan usus halus juga berpengaruh terhadap proses penyerapan. Panjang usus halus, panjang duodenum, panjang jejunum/ileum, lebar duodenum, dan lebar jejunum/ileum berhubungan sangat erat dengan berat tubuh unggas (Yao et al., 2006).

Hasil yang diperoleh dari proses digesti akan digunakan sebagai energi dalam aktivitas metabolismenya, dimana proses metabolisme tersebut dapat menambah massa sel dan volume sel sehingga bobot tubuh itik akan bertambah. Rata-rata berat badan dan panjang tubuh pada Itik Magelang, Itik Tegal dan Itik Pengging di Balai Pembibitan dan Budidaya Ternak non Ruminansia (BPBTNR) di Banyubiru Kabupaten Semarang memiliki perbedaan. Rata-rata panjang tubuh Itik Magelang $37.083 \mathrm{~cm}$, Itik Tegal $37.166 \mathrm{~cm}$ dan Itik Pengging yaitu $38.683 \mathrm{~cm}$. Rata-rata berat badan Itik Magelang adalah 149.01 gram, Itik Tegal 148.00 gram dan untuk Itik Pengging memiliki rata-rata Berat badan 153.00 gram. Perbedaan panjang tubuh dan berat badan tersebut juga mempengaruhi pemberian konsumsi pakan pada itik per harinya, Itik Magelang 160.00 g/ekor/hari, Itik Tegal 160.00 g/ekor/hari dan untuk Itik Pengging pemberian konsumsi pakannya $170.00 \mathrm{~g} / \mathrm{ekor} / \mathrm{hari}$ (Wulandari, 2015).

Berdasarkan hal diatas maka, akan dilakukan penelitian mengenai profil histologi duodenum berbagai itik lokal di Kabupaten Semarang. Mengingat untuk saat ini belum banyak peneliti yang melaporkan mengenai histologi duodenum yang mengacu pada perbedaan diameter lumen, tinggi vili dan jumlah sel goblet pada Itik Magelang, Itik Tegal dan Itik Pengging.

\section{BAHAN DAN METODE Waktu dan Tempat}

Penelitian dilakukan pada bulan September 2013. Pengambilan sampel berupa Itik Magelang, Itik Tegal, Itik Pengging dari Balai Pembibitan dan Budidaya Ternak non Ruminansia (BPBTNR) di Banyubiru Kabupaten Semarang. Pembedahan dan isolasi organ dilakukan di Laboratorium Struktur dan Fungsi Hewan, Jurusan Biologi Fakultas Sains dan Matematika Universitas Diponegoro.

\section{Bahan dan Alat}

Bahan yang digunakan, antara lain Itik Magelang, Itik Tegal, Itik Pengging, alkohol 30\%, alkohol 50\%, alkohol 70\%, alkohol 80\%, alkohol $90 \%$, alkohol $95 \%$, alkohol $100 \%$, air, garam fisiologis $(\mathrm{NaCl} 0,95 \%)$, larutan Bouin, tisu, kapas, kertas hisap, akuades, parafin cair, toluol, xylol, canada balsam, eosin dan hematoxylin.

Alat yang digunakan dalam penelitian, meliputi alat bedah lengkap yang terdiri dari gunting, jarum pentul, dan pisau bedah, mikroskop, bak parafin, gelas beker, botol spesimen, pipet, gelas ukur, kamera, kertas, kaca benda, kaca penutup, mikrotom putar, dan oven.

\section{Cara Kerja}

Persiapan hewan penelitian

Itik yang digunakan untuk penelitian dalam kondisi sehat berumur 6 bulan, Itik yang sehat dapat diketahui berdasarkan ciri-ciri, antara lain kondisi mata yang jernih, bulu tidak kusam, aktif bergerak, dan hidung tidak berlendir.

Menimbang bobot badan, dekapitasi dan isolasi intestinum Itik.

Pengambilan data dimulai dengan menimbang bobot badan itik dan panjang badan itik, setelah itu dilakukan dekapitasi dengan menggunakan metode kosher, kemudian dilakukan 
isolasi intestinum tenue dari tubuh itik. Metode kosher dilakukan dengan cara memotong pembuluh darah (vena jugularis dan arteri carotis), esofagus dan trachea (Koswara, 2009).

Pengukuran panjang intestinum tenue.

Setiap Itik Magelang, Itik Tegal dan Itik Pengging didekapitasi dan dilanjutkan dengan pembedahan. Pembedahan dilakukan untuk mengisolasi intestinum tenue dengan memotong pada bagian pangkal ventriculus hingga pada bagian rektum. Intestinum dicuci dengan menggunakan garam fisiologis selanjutnya dipotong $5 \mathrm{~cm}$ pada bagian duodenum. Potongan duodenum selanjutnya dicuci dengan menggunakan garam fisiologis $(\mathrm{NaCl}$ 0,95\%) kemudian difiksasi dengan menggunakan larutan bouin. Proses ini harus dilakukan dengan cepat agar organ tidak kering sehingga autolisis.

Pembuatan Preparat Histologi Duodenum (Saraswati dan Mardiati, 2004).

1) Duodenum sepanjang $5 \mathrm{~cm}$ dipotong menjadi ukuran $1 \times 1 \mathrm{~cm}$ kemudian difiksasi dengan menggunakan larutan bouin selama 24 jam.

2) Potongan duodenum tersebut selanjutnya dicuci dengan menggunakan alkohol bertingkat yang dimulai dengan konsentrasi 70\%, 80\%, 90\%, hingga $100 \%$.

3) Potongan duodenum kemudian didehidrasi dengan menggunakan toluol untuk selanjutnya masuk kedalam tahap infiltrasi parafin.

4) Potongan duodenum selanjutnya masuk dalam proses embedding (penanaman).

5) Potongan duodenum yang telah ditanam didalam blok parafin maka dilanjutkan dengan proses section (penyayatan) dengan menggunakan mikrotom putar.

6) Irisan duodenum yang telah diperoleh selanjutnya ditempelkan kedalam gelas benda dan diwarnai dengan menggunakan hematoxylin-eosin.

7) Irisan yang telah melekat pada gelas benda dimasukkan kedalam xylol, kemudian pindahkan kedalam alkohol dari konsentrasi tinggi ke konsentrasi rendah, selanjutnya dimasukkan kedalam aquades dan dikeringkan dengan kertas hisap.
8) Preparat dicelupkan kedalam larutan hematoxylin selama 5-10 detik selanjutnya, dibilas dengan menggunakan air mengalir selama 10 menit untuk menghilangkan zat warna dari bagianbagian yang seharusnya tidak terwarnai.

9) Preparat diamati dibawah mikroskop untuk melihat inti yang telah terwarnai, apabila belum terwarnai maka dicelupkan kembali kedalam larutan hematoxylin.

10) Preparat didehidrasi dengan menggunakan alkohol bertingkat.

11) Preparat dicelupkan kedalam larutan Eosin selama 5-10 menit kemudian dikeringkan dengan kertas hisap untuk selanjutnyadibilas dengan menggunakan alkohol.

12) Preparat diamati dengan menggunakan mikroskop untuk melihat sitoplasma, sitoplasma yang belum terwarnai secara sempurna dicelupkan kembali kedalam larutan eosin.

13) Preparat didehidrasi dengan menggunakan alkohol 70\%, 80\%, 90\%, 96\% lalu dikeringkan, kemudan dicelupkan kedalam alkohol absolut 3-5 adukan dan dikeringkan kembali dengan kertas hisap.

14) Preparat dimasukan kedalam xylol, kemudian diangkat dan ditetesi dengan canada balsem dan tutup dengan menggunakan gelas penutup.

Pengukuran diameter lumen, tinggi vili dan jumlah sel goblet pada duodenum.

Sediaan yang sudah diwarnai dengan pewarnaan hematoxylin-eosin diamati dengan menggunakan mikroskop dan didokumentasikan dengan kamera. Penentuan diameter lumen, tinggi vili dan jumlah sel goblet pada duodenum dengan menggunakansoftware MacBiophotonics ImageJ. Penentuan diameter lumen dan tinggi vili pada duodenum usus halus ditentukan berdasarkan ukuran terpanjang dan terpendek.

\section{Parameter Penelitian}

Parameter yang diamati yaitu panjang intestinum tenue, diameter lumen, tinggi vili dan jumlah sel goblet. 


\section{Desain Penelitian}

Desain Penelitian yang digunakan adalah tiga perlakuan dan enam ulangan.

\section{Analisis Data}

Data yang diperoleh dianalisis dengan uji ANOVA dan jika ada pengaruh berbeda nyata maka dilakukan Duncan Multiple Range Test (DMRT)

\section{HASIL DAN PEMBAHASAN}

Hasil analisis data penelitian berupa rerata panjang intestinum tenue, diameter lumen, tinggi vili dan jumlah sel goblet dengan menggunakan softwere SPSS dengan uji Anova dengan taraf kepercayaan $95 \%$ yang disajikan dalam tabel dibawah ini

Tabel .1. Hasil Analisis rerata panjang intestinum tenue, diameter lumen, tinggi vili, dan jumlah sel goblet ketiga jenis itik

\begin{tabular}{llrl}
\hline \multicolumn{1}{c}{ Variabel } & \multicolumn{1}{c}{ Magelang } & Tegal & \multicolumn{1}{c}{$\begin{array}{c}\text { Penggi } \\
\text { ng }\end{array}$} \\
\hline Panjang & $155.000^{\mathrm{a}} \pm$ & $153.670^{\mathrm{a}}$ & $158.000^{\mathrm{a}}$ \\
$\begin{array}{l}\text { Intestinum } \\
\text { Tenue }(\mathrm{cm})\end{array}$ & 19.463 & \pm 11.894 & \pm \\
$\begin{array}{l}\text { Diameter } \\
\text { Lumen }(\mu \mathrm{m})\end{array}$ & $1.669^{\mathrm{a}} \pm$ & $1.666^{\mathrm{a}} \pm$ & $18.681^{\mathrm{a}} \pm$ \\
& 253.835 & 283.401 & 234.205 \\
Tinggi Vili & $7.968^{\mathrm{a}} \pm$ & $9.8789^{\mathrm{a}} \pm$ & $8.377^{\mathrm{a}} \pm$ \\
$(\mu \mathrm{m})$ & 215.653 & 231.734 & 233.924 \\
Jumlah Sel & $5.016^{\mathrm{a}} \pm$ & $2.233^{\mathrm{b}} \pm$ & $3.116^{\mathrm{ab}}$ \\
$\begin{array}{l}\text { Goblet } \\
\text { dalam satu }\end{array}$ & 17.417 & 5.7154 & \pm \\
$\begin{array}{l}\text { vili } \\
\text { duodenum }\end{array}$ & & & 19.782 \\
\hline
\end{tabular}

Keterangan : Superskrip huruf yang sama pada baris yang sama menunjukkan tidak berbeda nyata pada uji duncan $(\mathrm{P}<0,05)$.

Berdasarkan hasil anova pada tabel 1 menunjukkan bahwa variabel panjang Intestinum tenue, diameter lumen dan tinggi vili pada masingmasing Itik Magelang, Itik Tegal, dan Itik Pengging berbeda tidak nyata $(\mathrm{P}>0.05)$.

Data tersebut didukung oleh penelitian Wulandari (2015) menunjukkan bahwa variabel konsumsi pakan, panjang tubuh dan bobot pada masing-masing itik berbeda tidak nyata. Konsumsi pakan yang dipengaruhi oleh perlakuan dengan pemberian konsentrasi pakan, dimana jumlah ransum pakan yang diberikan relatif sama yaitu masing-masing 160 gram/ekor/hari pada Itik Magelang dan Itik Tegal, sedangkan pada Itik Pengging 170 gram/ekor/hari (Wulandari, 2015). Waktu pemberian pakan juga sama yaitu rutin setiap pagi dan sore hari. Pakan merupakan komponen yang penting dalam usaha peternakan. Pakan mempunyai peranan penting untuk menopang struktur, anatomi dan fungsi intestinum tenue yang mempunyai konstribusi besar dalam meningkatkan pertumbuhan itik petelur. Intestinum tenue berperan menyerap monomermonomer yang dihasilkan dari pemecahan pakan berupa karbohidrat, protein, lemak, vitamin dan mineral dan didistribusikan keseluruh tubuh melalui aliran darah sebagai energi. Energi yang dihasilkan optimum dapat menjamin ketersediaan bahan baku metabolisme sehingga proses metabolisme didalam sel akan berlangsung secara efisien dan efektif. Energi yang dihasilkan dari pakan tersebut dapat digunakan sebagai pertumbuhan, pemeliharaan, dan produksi telur (Sunarno dan Djaelani, 2011).

Rerata ukuran intestinum tenue pada Itik Tegal yaitu $153.67 \mathrm{~cm}$ lebih pendek bila dibandingkan dengan rerata ukuran intestinum Itik Magelang yaitu $155.00 \mathrm{~cm}$ dan $158.00 \mathrm{~cm}$ pada ukuran panjang intestinum tenue itik Pengging. Panjang intestinum tenue bervariasi sesuai dengan ukuran tubuh, tipe makanan dan faktor lainnya (Rakhmawati dan Mei, 2014). Panjang intestinum tenue apabila dibandingkan dengan bobot badan, dapat diperoleh hasil bahwa bobot badan Itik Tegal yaitu $1480.0 \mathrm{~g}$, Itik Magelang yaitu $149.01 \mathrm{~g}$ dan bobot badan rata-rata Itik Pengging $1530.0 \mathrm{~g}$ (Wulandari, 2015). Panjang intestinumnya apabila dibandingkan dengan bobot badan itik maka semakin panjang intestinum tenuenya maka bobot badan akan semakin berat. Intestinum tenue memiliki ukuran panjang yang optimum sehingga bobot badan juga memiliki berat yang optimum. Hal ini karena panjang intestinum tenue mempengaruhi optimumnya proses penyerapan bahan makanan yang dicerna oleh intestinum tenue (Hamsah, 2013).

Ibrahim (2008) menyatakan bahwa panjang intestinum tenue berhubungan sangat erat dengan berat hidup secara signifikan. Variasi dalam 
ukuran-ukuran fisik intestinum tenue ternyata berpengaruh pada variasi-variasi dalam ukuran berat hidup. Variasi dalam ukuran-ukuran fisik intestinum tenue dapat berpengaruh pada kapasitas dan potensi intestinum tenue dalam mencerna dan menyerap zat-zat makanan bagi keperluan tubuh. Luas intestinum yang lebih besar dapat lebih memperbesar volume makanan yang dapat ditampung, dicerna, dan diserap oleh pembuluh darah vena portae lalu diangkut ke hepar. Luas penampang intestinum tenue merupakan salah satu faktor penting yang berpengaruh pada kecepatan pertumbuhan unggas. Luas penampang intestinum tenue dipengaruhi oleh ukuran panjang dan lebarnya.

Berdasarkan hasil analisis tinggi vili yang disajikan dari tabel diatas menunjukkan bahwa tinggi vili berbeda tidak nyata pada masing-masing itik Magelang, Itik Tegal dan Itik Pengging. Rerata ukuran tinggi vili Itik Magelang yaitu $7.9688 \mu \mathrm{m}$, sementara untuk rerata tinggi vili Itik Tegal yaitu $9.8789 \mu \mathrm{m}$ dan rerata ukuran tinggi vili itik Pengging yaitu $8.3776 \mu \mathrm{m}$. Vili merupakan bagian dari permukaan selaput lendir yang menunjukkan penjuluran berbentuk jari. Vili tersebut memiliki penjuluran sitoplasma yang disebut mikrovili. Mikrovili dapat meningkatkan permukaan penyerapan sehingga kinerja vili dalam proses absorbsi menjadi lebih optimum (Dellman dan Brown, 2009). Rerata ukuran panjang vili yang tinggi dapat memaksimalkan proses absorbsi nutrisi dari pakan, sehingga dalam proses absorbsi yang optimum maka nutrisi yang digunakan dalam aktivitas metabolisme akan lebih optimum. Energi yang diperoleh dari aktivitas metabolisme digunakan untuk pertumbuhan dan perkembangan badan itik terutama dalam proses produksi telur. Pertumbuhan dan perkembangan itik ditandai dengan meningkatnya massa dan volume sel, sehingga bobot dan panjang itik semakin tinggi. Sehubungan dengan hal ini, pertumbuhan tinggi villi intestinum tenue berhubungan erat dengan potensi intestinum tenue dalam menyerap sari-sari makanan. Semakin tinggi villi intestinum tenue, semakin besar efektifitas penyerapan sari-sari makanan melalui epitel intestinum tenue (Lenhardt and Mozes, 2003).

Proses penyerapan nutrisi yang terjadi didalam intestinum tenue akan menambah bobot tubuh itik dan meningkatnya produktivitas telur itik. Kemampuan unggas dalam mengkonversi ransum menjadi daging dan telur berkaitan erat dengan fungsi saluran pencernaan terutama intestinum tenue (Royani, 2012). Proses penyerapan yang terjadi didalam duodenum dioptimumkan dengan adanya vili yang menjulur disepanjang permukaan lumen. Setiap villus mengandung pembuluh kapiler dan pembuluh limfa (lakteal). Proses penyerapan tersebut dibantu juga oleh permukaan villi terdapat banyak mikrovili yang berfungsi melakukan proses absorpsi terhadap hasil pencernaan (Suprijatna, 2005).

Meningkatnya panjang dan berat intestinum tenue maka semakin meningkat pula permukaan bagian dalam dan luas permukaan intestinum tenue, sehingga dalam taraf tertentu terjadi peningkatan daya cerna dan daya serap sari-sari makanan oleh intestinum tenue (Yao et al., 2006).

Berdasarkan hasil analisis diameter lumen yang disajikan pada tabel diatas 4.1 menunjukkan bahwa berbeda tidak nyata pada masing-masing Itik Magelang, Itik Tegal dan Itik Pengging. Rerata diameter lumen Itik Magelang yaitu 1.6698 $\mu \mathrm{m}$, sementara untuk Itik Tegal nilai rerata diameter lumen yaitu $1.6669 \mu \mathrm{m}$ dan untuk nilai rerata diameter lumen yaitu $1.6213 \mu \mathrm{m}$. Diameter lumen didalam intestinum merupakan salah satu indikator banyak sedikitnya pakan yang dapat ditampung didalam lumen. Ukuran diameter lumen yang besar mampu menampung pakan yang lebih banyak, sehingga proses absorbsi nutrisi akan lebih maksimal. Absorbsi merupakan suatu proses aktif dari kemampuan sel epitel dalam menyerap secara selektif zat-zat seperti glukosa, galaktose dan fruktose (Frandson, 1992).

Berdasarkan hasil analisis jumlah sel goblet yang disajikan pada tabel diata 4.1 menunjukkan bahwa berbeda nyata pada Itik Magelang dengan Itik Tegal, tetapi tidak berbeda nyata pada Itik Pengging. Rerata jumlah sel goblet pada Itik Magelang yaitu 5.0166, untuk rerata jumlah sel goblet pada Itik Tegal yaitu 2.2333 dan untuk rerata jumlah sel goblet Itik Pengging yaitu 3.1166. Jumlah sel goblet tersebut akan mempengaruhi produksi lendir didalam duodenum. Sel Goblet mensintesis granula yang bersifat netral yang mengandung glikoprotein dan 
asam sialat. Mukus yang dihasilkan oleh sel Goblet memberi perlindungan permukaan usus halus dari ancaman invasi Ascaridia galli dan mukus yang dilepaskan oleh sel Goblet membatasi gerakan cacing dengan cara menutupi kutikulanya sehingga tidak mampu mengadakan perlekatan pada mukosa usus dan dengan bantuan peristaltik cacing Ascaridia galli dikeluarkan dari tubuh (Balqis, 2015). Ayam kampung yang terinfeksi cacing Ascaridia galli, pertumbuhannya menjadi terhambat hingga $38 \%$ sehingga pada akhir pemeliharaan didapat bobot badan yang rendah, dan menyebabkan terjadinya penurunan berat telur hingga 5,35\%, kerabang telur lebih tipis dengan persentase penurunan tebal kerabang sebesar $5,55 \%$, warna kuning telur jauh lebih pucat sebesar 11,63\% (Zalizardkk., 2007). Tabel 4.1 menunjukan bahwa jumlah sel goblet pada Itik Magelang lebih tinggi bila dibandingkan dengan yang Itik Tegal dan Itik Pengging, hal ini didukung dengan data sekunder bobot tubuh yang menunjukkan bahwa rerata bobot badan Itik Magelang yaitu $149.01 \mathrm{~g}$, Itik Tegal yaitu $1480.0 \mathrm{~g}$ dan bobot badan rata-rata Itik Pengging $\quad 1530.0$ $\mathrm{g}$

Sel goblet merupakan sel yang panjang, ramping dan bertanggung jawab dalam produksi lendir. Lendir yang dikeluarkan merupakan bagian penting dari keseimbangan pencernaan dan dapat membantu memindahkan pakan melalui lambung, usus, dan usus besar. Sel-sel ini terletak di lapisan epitel dinding organ seperti trakea, bronkus, usus halus, membran kelopak mata atas, usus besar, dan lain-lain. Sel-sel goblet terselip antara sel-sel absorbsi (Sel toraks). Sel toraks adalah sel-sel absorptif yang ditandai oleh adanya permukaan apikal yang mengalami spesialisasi yang dinamakan "striated border" yang tersusun atas mikrovili. Striatedbordermerupakan tempat aktivitas enzim disakaridase usus halus. Enzim ini terikat pada mikrovili, menghidrolisis disakarida menjadi monosakarida, sehingga mudah diabsorbsi. Di tempat yang sama diduga terdapat enzim dipeptidase yang menghidrolisis dipeptida menjadi unsur-unsur asam aminonya. Fungsi sel toraks adalah mengabsorbsi sari-sari pakan yang dihasilkan dari proses pemecahan.. Sel goblet berfungsi menghasilkan glikoprotein asam yang berfungsi melindungi dan melumasi sel pembatas usus halus (Junqueira dan Carneiro, 2007).

\section{KESIMPULAN}

Berdasarkan hasil penelitian dan pembahasan, maka dapat ditarik kesimpulan bahwa variasi jenis itik tidak berpengaruh pada struktur intestinum tenue. Jumlah sel Goblet menunjukan bahwa Itik Magelang dan Itik Tegal berbeda nyata, tetapi berbeda tidak nyata dengan Itik Pengging.

\section{UCAPAN TERIMA KASIH}

Terima kasih kepada Dr. Tyas Rini Saraswati, M.Kes dan Dr. Enny Yusuf W. Yuniwarti, MP atas diskusi dan masukannya terhadap penulisan jurnal ini.

Terima kasih kepada Laboratorium Biologi Struktur dan Fungsi Hewan Jurusan Biologi FSM UNDIP atas dana penelitian yang diberikan.

\section{DAFTAR PUSTAKA}

Balqis, U., M. Hanafiah,. C. Januari., M. Nur Salim, Siti Aisyah, dan Y. Fahrima. 2015. Jumlah Sel Goblet Usus Halus Ayam Kampung (Gallus domesticus) yang Terinfeksi Ascaridia galli Secara Alami. Jurnal Medika Veterinaria vol. 9 No 1 Februari 2015

Dellman, H. D dan Brown, E. M. 2009. Buku Teks Histologi Veteriner. Alih Bahasa: R. Hartono. UI Press, Jakarta.

Frandson, R.D., 1992. Anatomi Dan Fisiologi Ternak edisi keempat. Gadjah Mada University Press.Alih bahasa oleh Bambang Srigandono dan Koen Praseno. Gadjah Mada University Press. Yogyakarta.

Hamsah. 2013. Respon Usus dan Karakteristik Karkas pada Ayam Ras Pedaging dengan Berat Badan Awal Berbeda yang Dipuasakan Setelah Menetas. Skripsi. Jurusan Produksi Ternak. Fakultas Peternakan Universitas Hasanudin. Makassar.

Ibrahim, S. 2008. Hubungan Ukuran-Ukuran Usus Halus Dengan Berat Badan Broiler. Jurusan Peternakan Fakultas Pertanian 
Universitas Syiah Kuala. Banda Aceh. $J$. Agripet Vol 8:2 Oktober 2008

Junqueira, L.C dan Carneiro, J. 2007. Histologi Dasar edisi 10. Penerbit EGC. Alih bahasa oleh Adji Dharma.

Koswara, S. 2009. Pengolahan Unggas. EbookPangan.com. 28 Mei 2015.

Lenhardt, L. and Mozes, S., 2003. Morphological and functional changes of the small intestine in growth-stunted broilers. Acta Vet. Brno. 72:353-358.

Murti, A. 2003. Studi Anatomi Organ-Organ Pencernaan(Digesti) Kukus Bertotol (Spilocuscus maculatus). Skripsi. Jurusan Produksi Ternak. Fakultas Peternakan Perikanan dan Ilmu Kelautan. Universitas Negeri Papua. Manokwari

Rakhmawati, R. dan Mei, S. 2014. Rekayasa Pakan Melalui Biofermentasi Limbah Ikan Terhadap Presentase Karkas dan Panjang Usus pada Ayam Broiler. Program Studi Pendidikan Biologi. Universitas PGRI Semarang. Jurnal BIOMA. vol 3:2 Oktober 2014.

Royani, M. 2012. Efek Waktu Mulai Pemberian Ransum setelah Menetas dan Implikasinyaterhadap Penampilan Ayam Broiler. Universitas Padjadjaran. Jurnal IJAS vol. 2:1 2012

Ruttanavut, J., K. Yamauchi, H.Goto and T. Erikawa. 2009. Effects of Dietary Bamboo Charcoal Powder Including Vinegar Liquid on Growth Performance and Histological Intestinal Change in Aigamo Ducks. Kagawa University. Japan. International Journal of Poultry Science 8(3):229-236.

Saraswati, T.R dan S. M. Mardiati. 2004. Buku Penuntun Praktikum Mikroteknik Hewan. Jurusan Biologi Fakultas Sains dan Matematika. Universitas Diponegoro. Semarang.
Setiawan, N. 2006. Perkembangan Konsumsi Protein Hewani di Indonesia : Analisis Hasil Survey Sosial Ekonomi Nasional 2002-2005. J. ilmu Ternak 6(1): 68-74.

Sugito, M., W., Astuti, D. A., Handharyani, E. dan Chairul.,2007. Morfometrik usus dan performan ayam broiler yang diberi cekaman panas dan ekstrak n-heksana kulit batang 'jaloh'(Salix tetrasperma Rozb). Media Peternakan 30:198-206.

uprijatna. 2005. Ilmu Dasar Ternak Unggas. Penebar Swadaya. Jakarta.

Sunarno dan M. A. Djaelani. 2011. Analisis Produktivitas Itik Petelur di Kabupaten Semarang Berdasarkan Indikator Nilai Konversi Pakan, Rasio Tingkat Konsumsi Pakan dengan Intestinum dan Bobot Intestinum dengan Pertambahan Bobot Badan. Laboratorium Biologi Struktur dan Fungsi Hewan, Jurusan Biologi, Fakultas Sains dan Matematika Universitas Diponegoro. Jurnal Sains dan Matematika vol 19(2):38-42 (2011).

Wulandari, D. 2015. Perbedaan Somatometri Itik Tegal, Itik Magelang dan Itik Pengging. Skripsi. Jurusan Biologi Fakultas Sains dan Matematika. Universitas Diponegoro Semarang.

Yao, Y., Xiaoyan, T., Haibo, X., Jincheng, K., Ming, X. and Xiaobing, W., 2006. Effect of choice feeding on performance gastrointestinal develo-pment and feed utilization of broilers. Asian-Aust. $J$. Anim. Sci. 19:91-96.

Zalizar, L., F. Satrija, T. Risa, dan A.A. Dewi. 2007. Respons Ayam yang Mempunyai Pengalaman Infeksi Ascaridia galli terhadap Infeksi Ulang dan Implikasinya terhadap Produktivitas dan Kualitas Telur. Animal Production. 9(2):92-98. 